IKONOMIKA: Jurnal Ekonomi dan Bisnis Islam

Volume 5, No I (2020)

ISSN : 2527-3434 (PRINT) - ISSN: 2527-5I43 (ONLINE)

Page : $43-54$

\title{
Islamic Leadership Accountability Of Umar Bin Abdulaziz: A Lessons Towards A Good Governance In Nigeria
}

\author{
Aliyu Ibrahim Musaddad ${ }^{\mathrm{I}}$, Abubakar Mohammed Inuwa ${ }^{2}$ \\ Department of Islamic Studies, Faculty of Arts, \\ Nasrawa State University Keffi, Nigeria ${ }^{1,2}$ \\ aliyumusaddad@,nsuk.edu.ng ${ }^{1}, \underline{\text { InuwaabuI@gmaiul.com }}{ }^{2}$
}

\begin{abstract}
There is no doubt leadership has been given a tremendous place and a key positioning in Islam, Qur'an, Sunnah and the consensus of Ulama'u (Muslim scholars) have made it apparent about the necessity of leadership among the Muslim community. Most recently, the issue of leadership in Nigeria has become a major concern to the Nigerians. Whilst some research has been conducted to examine the solutions to Nigerian leadership, little attention has been paid to Islamic approaches of accountability which is the vital pillar of governance as the key towards sustainable leadership in Nigeria. This study therefore seeks to explore the lessons from leadership and accountability during the caliphate of Umar bin Abdulaziz (R.A) as a panacea to Nigerian Leaders. The methodology of the study relies on critical and comprehensive analysis of the existing published literature related to the topic. Hence, data collection is effected through the qualitative method. The findings of this study revealed that there are lots of lessons and wisdoms that Nigerian government could acquire from the history of caliphate Umar such as his reformations and innovations in governing the state as reflected in siyasah shar'iyyah which can be solution for practicing good governance in Nigeria. Based on the findings, it was recommended that fear of Allah and believing in accountability is the best option for leaders.
\end{abstract}

Key words: Leadership, Islam, Model, Accountability, Good Governance. 


\section{A. INTRODUCTION}

There is no doubt leadership has been given a tremendous place and a key positioning in Islam, Qur'an, Sunnah and the consensus of Ulama'u (Muslim scholars) have made it apparent about the necessity of leadership among the Muslim community.

It is clear about the importance of leadership in Islam; associating the obedience to Allah Himself with the obedience to leaders. However, a number of traditions of the Prophet SAW have equally indicate the vitality of leadership and that it is the bedrock for sustaining of the setup of a nation.

IbnTaymiyyah (I300:32) observrd that In Islam, Leadership is a great societal responsibility that the successes of discharging its obligations depend on adequate justice and handling of matters fairly.

According to Mawdudi (1982:I0)As a representative, a ruler is just an active executive to people according to the law of Allah. In this regard, he must ensure justice and fairness in all his dealings with the public trust under his custody. Leadership in Nigeria has been contaminated with ridicules. There are so many cases of aversive corruption, unemployment, insecurity violation of human right, embezzlement of public fun, extrajudicial killing and the general misconduct. Nigeria is no doubt a rich Nation and even one of the largest oil producing country which its citizens should not be suffering too much from earning living, social structures, education, health and the rest of them. But the true fact is that Nigerians lives revolve around a very low income, the economy is so deteriorated. The worse of the situation is that Nigerians are in many cases living in internally displaced refugee camps a condition caused by insecurity in the country. The US had the following account on Nigeria:

Corruption in Nigeria is no longer a gossip it has glaringly become endemic that engulfed every sector and virtually every group of people. The scourges and detrimental effects of corruption in Nigeria are quite manifested in the wreckage in political, social, economic, educational and religious grandeurs of the Nigerian societies. Several administrations have vowed to debunk corruption and hence many agencies were established but their efforts appear to be abortive. Policies and decrees were enacted to quench the flame of corruption but all in vain. In this regard, this research is designed to carefully appraise the lessons from leadership and accountability during the caliphate of Umar ibn Abdul'aziz to Nigeria Leaders. One of the disturbing fact for instance is that, it is always said that Nigeria as a country, is blessed with almost all the resources; ranging from human beings in terms of population and intellect, natural including petroleum product and solid 
minerals, and even the animals are not scarce in the country. Despite all these, the recurrent problem that Nigerians experiences over some decades is nothing but lack of good leadership. The crusade against corruption in the past by many leaders yielded no any positive result.

Complex problems have therefore faced in Nigerian Leadership Style hence the need to know and appreciate the Islamic approach is paramount. It is against this background that this study seeks to explore the lessons from leadership and accountability during the caliphate of Umar bin Abdulaziz (R.A) to serve as a panacea to Nigerian Leaders.

\section{B. THEORITICAL}

\section{Accountability in Islamic Leadership}

An effective leadership is responsible for the whole destiny of the followership and is, therefore, accountable for the stewardship and conduct of the affairs of the whole society. Tukur (2009: I00-IOI) cited Zayyad that accountability denotes "a sense of responsibility in those who are called upon to account”. On the same note, Tukur points to the position of Bird that; accountability places two obligations upon a steward; he must account of his dealings of resources on one hand and submit the account on behalf of a person or body to whom he is accountable on the other hand.

This is the point impressed by the hadith of the Prophet which begins with the general but firm statement:

Every one of you is a shepherd and every one of you is responsible for his flock (Bukhari, Bukhari 5, vol 3 Hadith No 32).

This is in line with the fact that, Umar bin Al-Khattab used to confiscate half of the properties discovered to be owned by his governors that cannot justify how they acquired them after becoming public officers. Such surplus wealth has to be deposited in the state treasury. Tukur (2009:30) also attested to this position by asserting that;

A leader, in the tradition of Caliph Umar, should not 'wear the clothes, eat choice food or employ chamberlain. The same caliph established the habit of refusing gifts and opposed the tendency to acquire wealth among public servant. He instituted the practice of confiscating half of the governor's possession that they were not previously known to possess.

A leader, therefore, is a trustee of the whole community as such he is responsible to account for all his actions as it relate to his leadership style. His accessibility to the 
ordinary members of the community can be seen as a form of accountability. Accountability to people entails, also, pre-occupation with listening to their complaints and punishing the officials who wrong them and the desire to make them happy not making them tired of their ruler nor forsake him. However, Tukur (2009:105) observes that:

Accountability to Allah is fundamental to Islamic political thought. From the qualification for election to positions of authority to the act of bay'a and the justificatory principles on which policies and actions are based, concern with the hereafter, and with the type of reward which Allah may give for creditable performance and behavior, it is clear that the importance of this type of accountability cannot be gainsaid.

In the same vein, Tukur (2009:I4) points out that Shaykh Uthman bin Fodiyo asserted that;

In Islam public responsibility and leadership are a trust. Whatever positions a person holds in any public office he/she is definitely holding a trust.

From the foregoing, it obvious that Islam stresses the need for honesty, trustworthiness and probity to be an integral part of Islamic belief system. This indicates that; a Muslim is guided by his faith in carrying out the obligations expected of him and in keeping his trust. He is also aware of the fact Allah shall call him to account for his actions. This kind of accountability and public trust envisaged by Islam is most enduring, sincere and potent in safeguarding the actions of people in their public and private services respectively.

\section{Biography of Umar bin Abdulaziz}

According to Hakam (1967: 2) Umar was on 2 November 682 in Medina, equivalent to $60 \mathrm{AH}$. His father ruled over Egypt as viceroy to the caliph. He grew up and lived there until the death of his father, after which he was summoned to Damascus by Abd al-Malik and married to his daughter Fatima. His father-in-law would die soon after, and he would serve as governor of Medina under his cousin Al-Walid I.

Ash-Sallabiy (2006: 2) remarked that Umar was extremely pious and averse to worldly luxuries. He preferred simplicity to extravagance. He deposited all assets and wealth meant for the ruling caliph into the Bait Al Maal. He even abandoned the royal palace and preferred to live in a modest house. He wore rough clothes instead of royal robes and often went unrecognized in public like his great grandfather Caliph Umar ibn Al Khattab. 
After his appointment as caliph he discarded all the pompous appendages of princely life-servants, slaves, maids, horses, palaces, golden robes and real estates and returned them to Bait Al-Maal. He also asked his wife Fatima to return the jewelry she had received from her father Caliph Abdul Malik. The faithful wife complied with his bidding and deposited all of it in the Bait Al-Maal. Later, he got his articles of luxury auctioned for 23,000 dinars and spent the amount for charitable purposes. He never built a house of his own.

When news reached him of his nomination to the Caliphate, he addressed the people saying, "O people! The responsibilities of the Caliphate have been thrust upon me without my desire or your consent. If you choose to select someone else as the Caliph, I will immediately step aside and will support your decision". This was a breath of fresh air to the people who were longing for a return to the days of Prophet Muhammad (may God praise him) and the Rightly Guided Caliphs Hakam (I967:8).

After his appointment as caliph, he discarded all the pompous appendages of princely life-servants, slaves, maids, horses, palaces, golden robes and real estates and returned them to Bait al-Mal. Not only that but he also asked his wife Fatima to return all the jewelries she had received from her father caliph Abdulmalik. The faithful wife complied with him and deposited them to the public treasury. Umar auctioned his articles of luxury and spent the money on charitable purposes. Moreover, Umar had never built a house of his own. Lukman (I995:4I).

Lukman (42) reported It was during his time that Islam took root and was accepted by a large segment of the population of Persia and Egypt. When the officials complained that because of conversion, the Jizyarevenue of the State had experienced a steep decline, Umar wrote back saying that Prophet Muhammad SAW was sent as a Prophet to invite people to Islam and not as a tax collector. He abolished home tax, marriage tax, stamp tax and many other taxes as well. Umar bin Abdul'Aziz was able to carry out his leadership responsibility in a successful way and one of the factors that helped him in doing so was that he had good advisers who included his own sons and wife. Above has clearly indicated the personality, ideology and believes of Umar bin Abdul'Aziz as caliph (43).

When previously there was no answerability to the people, Omar reestablished accountability and abolished the corrupt practices by which the government officials had become rich, powerful and abusive. The people responded with enthusiastic support and overall productivity throughout the Islamic State increased. Renowned Islamic scholar, IbnKathir, records that because of the 
reforms undertaken by Omar, the annual revenue from Persia alone increased from 28 million dirhams to I24 million dirhams (Al-Ghazali (I427: 548).

Umar's efforts to transform the Islamic Islamic State into a well-run Islamic community knew no bounds. Just as he transformed his life he also transformed the Islamic State. Omar undertook extensive public works throughout the Islamic State in Persia, Khorasan (includes parts of modern day Iran, Afghanistan and central Asia) and across North Africa. This included roads, bridges, canals, inns for travellers, educational facilities and medical dispensaries. Lukman (1995:52).

Umar Ibn Abdul Aziz became known as a rightly guided Caliph of the Islamic nation because of his similarity to the Rightly Guided Caliphs. The Rightly Guided Caliphs learned their practice of Islam straight from Prophet Muhammad (SAW). However after their death the Caliphate became a dynasty and a more lax approach was taken to implement certain commandments. Lukaman (1995:52).

Umar Ibn Abdul aziz revived righteous Islamic principles and began to put jewels into the crown of the Islamic Empire. One of his first acts was to replace corrupt and tyrannical Umayyad administrators with honest and just people and another was to restore to the rightful owners their properties that were confiscated from them. Within the first ten years of the conquest of Sindh (part of modern day Pakistan), in 718 CE Omar became the first Caliph to commission a translation of the Quran from Arabic into another language - Sindhi. This was at the request of the Raja of Sindh. Sindh was yet another area of the Islamic State conquered by the will of God and the impeccable Islamic morals and manners of war, not known in other parts of the world at that time Lukman (1995:54).

At the same time Omar's armies waged a defensive war against the Turks who had ravaged Azerbaijan and massacred thousands. Omar permitted his forces to wage war only under strictest conditions, including that women, children or prisoners would not be executed, and that a fleeing, defeated enemy would not be pursued.

Amongst many firsts, Umar bin Abdul Aziz was the first Muslim ruler to turn his attention away from external conquest. He recalled the Muslim armies from the borders of France, India and the outskirts of Constantinople. It was during his Caliphate that internal uprisings and disturbances ceased, and the true Islamic faith taught by Prophet Muhammad, may God praise him, flourished once again. Greed however does not surrender to faith without a battle, thus there were many disgruntled people, unhappy with Omar's rule. Yet the reforms continued. Under Omar's instructions the viceroy in Spain, took a census of the diverse nationalities, races and creeds, inhabiting that section of the Empire. A survey of 
the entire peninsula including cities, rivers, seas and mountains was made. Yusuf (20I9: 4I).

The nature of the soil and varieties of mineral sources and agricultural produce was carefully counted and recorded, bridges in southern Spain were constructed and repaired and a large mosque was built at Saragossa in northern Spain. In the time between the Rightly Guided Caliphs and Omar IbnAbdulaziz the Public Treasury was freely used for private purposes by the Umayyad Caliphs. Omar immediately put a stop to this practice but at the same time made himself a number of dangerous enemies. Nevertheless he continued to institute reforms and revivals that caused the poor, weak and righteous Muslims to feel strong and protected as they once had under the early Caliphs. Yusuf (2019:42).

Yusuf (2019) observerd One of the most important measures was his reform of taxation. Omar Ibn Abdul Aziz, following in the footsteps of his beloved prophet Muhammad was kind and just toward non-Muslims. Christians, Jews and Zoroastrians were allowed to retain their churches, synagogues and temples. In Damascus, where the Basilica of John the Baptist had been turned into a mosque, Omar ordered it returned to the Christian church (55). Umar's administration of the Empire was impartially just and went directly against the interests of the Umayyad dynasty, of which Omar was a distant member but far from the line of succession. The influential Umayyad's could not tolerate their loss of power, prestige and finances. Omar's reforms were too much for them to tolerate.

To sum up the idea here it could be seen that there are some main factors that helped caliph Umar in recording the great success he had recording which the pages of the history will never forget, these include the following:

a. Piety

b. Association with Good People

c. Fear of Allah

d. Compassion

e. His Verse Knowledge

His reforms in favor of the people greatly angered the nobility of the Umayyads, and they eventually bribe a servant into poisoning his food. Umar learned of this on his death bed and pardoned the culprit, collecting the punitive payments he was entitled to under Islamic law but depositing them in the public treasury. Hakam (1967:66). He died in February 720 (on Friday the six of Rajab which is the eight month of the Islamic calendar in the year IOI AH, when he was forty one old). Umar's reign lasted for two years or thirty month as according to some historical 
accounts. (Hibban, Vol. 2, 566). He was succeeded by his cousin Yazid II. AlGhazali (I427:549).

\section{METHODOLOGY}

The study thus, pursues to reconnoitre the lessons from leadership and accountability throughout the caliphate of Umar bin Abdulaziz (R. A) as a remedy to Nigerian Leaders. The method of the study be dependent on on critical and inclusive analysis of the existing published literature related to the topic. Hence, data collection is effected through the qualitative method.

\section{Good Governance During Umar's Reign}

Debeil (20II: I)The issue of good governance has become trending topic in resolving societal well-being. It has become a truism to say that good governance is essential for successful development. Then a simplest question raise up is what really is in good governance? To begin with, there are various definitions of governance. It can be either broad or narrow definitions.

In Islamic perspective, concept of siyasahsyar'iyyah has similar objective and meaning with the concept of good governance.Actually, the term siyasahshar'iyyah have used in many purpose. According to Ibn Manzur (I969) in his book - lisanarab, there are two words here, namely; siyasah and shar'iyyah. The word siyasah, literally derived from the Arabic language — sasa, meaning to arrange, to manage, to rule and politics. The basic purpose of siyasah is to arrange, manage, and use political wisdom to achieve certain objectives (Ismail and Ab. Rahman, 20II). Hence when the term is compounded with shari'ah, it becomes a shari' public policies, or government accordance with the shariah. Falaki (2007: 8).

Relating to the practice of the concept and principles of al-siyasah al-shyar iyyah, in the new context of what is known as Good governance, Ash-Shallaby (2006:I8) comment that Caliphate Umar b. Abdulaziz has established successful history in his almost three years leadership. When he was appointed as khalifah (the leader) his governance was characterized by innovation, reformation, and high accountability. Umar was able to manage and bring Umayyad toward a prosperous and wealthy reign. People called him as Umar II, as the fifth khalifah after, Abu bakar, Omar, Usman, Ali and the fifth is Umar bin Abdul Aziz.

To begin with his duties, In general, there are four things that Omar did relating to the general principles of siyasahshar'iyyah. The revitalization and upgrading made by Umar are as follows: 


\section{a. Shura (consultation) \\ b. Amanah (Trust) \\ c. $A d l$ (Justice) \\ d. AmruBilMa'rufWan Nahyu AnilMunkar(Promote the Benefit and Prevent the Harm)}

\section{RESULTS AND DISCUSSION}

\section{Lessons from Umar's Leadership Style to Nigerian Politicians}

Nigeria, classified as being the Giant of Africa beard the rate abstractly due to negligence of accountability in governance from our leaders and this constituted to its rate to remain underdeveloped. The objective of most of the leaders is to achieve the mandate goals, but failed to believe that no one can attain any post without the knowledge of the divine (Allah) and any leader who fail to have it at the back of his mind that believing in sovereignty and implementation of accountability is the best option for a leader to descend well.

There are political principles in Islam exemplified during the reign Umar b. Abdulaziz which will serve as a guide to leader to succeed in the governance. These include: sovereignty of Allah, justice, equality. As the Prophet stated it that everyone is a leader in one way or the other and shall be questioned to account for his or her deeds. Falaki (2007: 88).

The justice Umar Abdulaziz plays and accountability style he adopts among Muslims, Christians and the Jews during his reign made his reign to succeed and everyone live in peace and harmony; it also enhanced orderliness, stability and great development in the state. if the Prophet's style is followed.

The reign of Umar Abdulaziz displayed Justice and human brotherhood as bases of equal treatment and respect for individual, irrespective of their race, colour, age, sex or nationality. This, is adopted in Nigeria will be create better environment for peace and the well being of human and security of life, property and honour individual freedom, education social solidarity, minimization of crime, and tension long term development of a society cannot be sustained if these requirements are missing in the society. Falaki (2007: 83)

The well-being of all the people living on earth irrespective of their race, colour, age, sex or nationality is one of the lesson learned during Umar Abdulaziz leadership, it should be adopted to create better environment and peaceful coexistence in Nigeria.

Some of the notable gaps identified in the Nigerian governance of which the 
leadership style of Umar Abdulaziz can solve enumerated below:

1. The problems we have in Nigeria today with our leaders arise from the absence of justice and fair play. Xenophobia attack pugnacity, political imbroglio, economic entanglement, socio-religious tension and the likes would be thing of the past if leaders should adopt the Islamic Political Principles, the components of sovereignty of Allah, living life of accountability, justice and equality before the law, believing in culture of value in taking welfare priority and true love for others as the prophet said: You are not a true believer until you want for other fellow being exactly what you want for yourself. (Bukhari, Book 43, No. 332)

2. Nigeria just above 50 years of indifference and have fought a civil war. We must understand that Nigeria cannot survive another civil war. Politician should not see the traditional institution as a threat but they should work with it to develop the country. Leaders should always lead exemplary life style worthy of emulation by their subject.

3. Nigerian Leaders should accept criticism: "I don't see criticism as anything and I am not bothered whenever I am being criticized by the public. I know that some people would love me, so I do not let that disturb me. Leaders like Umar Abdulaziz are bothered by their criticism. The criticism only makes me a better person, so when people say negative things about me, it makes me understand that I cannot be right every time. I thank God that I am now getting some things right. Though this assertion by Toyin, we can conclude that when our leaders accept criticism and listen to people to put things in place, everything will be all right as exemplified by Umar Abdulaziz.

\section{E. CONCLUSION}

The Islamic political principles are used as benchmark for gauging good governance; these are sovereignty, justice equality before the law and most importantly accountability which formed the focus of this study. If it looked back to the eight principles of good governance that Kofi Annan stated, it can be see that Omar did all of these requirements such as promoting the rule of law, accepting of minority and opposition groups, transparent political processes, a neutral judiciary, an unbiased police force, a military that is strictly subject to civilian control, a free press and vibrant civil society institutions and admiration of human rights. From the siyasahshar' 'yyah perspective the foundation of Islamic state as the main values such as justice (adl), trust (amanah), Consultation (shura) and promoting benefit and prevent harm (amrubilma'tuf wan nahyuanilmunkar) implemented well by Omar. Straight away chosen as khalifah, he reshuffles and reforms the whole system of 
administration and all kind related to it also changed. There are three broad categories of reconstruction and reformation, during two years and half, namely religious sector administration sector and Economic sector. As a result, the people gained economic, social, and political benefits and prosperity with the faith to God. Needless to say, Omar implement Islamic values in his administration. This is evidence that the value of Islam is merely not a theory but the values that can be implemented in daily life.

The leadership style exemplified by Umar gave al-Ghazaliinsight into formulating ten principles as requirements to achieve the prosperity and the welfare of the country.

There are lots of lessons and wisdoms that the government could acquire from the history of caliphate Umar such his reformations and innovations in governing the state. Therefore, it is good to introduce the concept of siyasahshar'iyyah widely which is it can be solution for practicing good governance.

\section{Recommendations}

Based on the findings of this study, the following suggestions and recommendations were proffered:

i. Fear of Allah and believing in accountability is the best option for leaders.

ii. Leaders should by principles maintain neutrality in inter-religious affairs because Nigeria is a multi- religious society.

iii. Anyone who Allah bestow power on should be grateful to Allah, should not be celebrating but rather sleepless to ensure people's welfare and satisfaction Families should inculcate social justice into their children.

iv. Leaders should treat their subject with kindness and live the life of accountability.

\section{REFERENCE}

Abdul, M.O. : 1980 :The Classical Caliphate. Lagos: Islamic Publication Bureau. Al-Bukhari M.I.: (I422AH): Sahih al-Bukhari. np: Darudauq al-Najat,. Al-Ghazili M.: (I427AH) fiqh al-Sirah. Damascus: Dar al-Qalam. Ali M: (I429AH):. Al-Daulat al-Umawyyat. Beirut: Dar al-Ma'rifa.

Ash-Sallaby, Ali Muhammad : (2006):,.Min a"lamTarikh al Islam: Amir al Mukminin Omar bin "Abd al Aziz, Ma"alim al tajdidwa al islah al Rashidi „alaMinhaj al Nubuwah. Dar al Tawzi“ wa al Nashr al Islamiyah, Cairo. 
Debiel, Tobias et al., 20II. Goodbye to Good Governance? How Development Discourse Copes with State Failure, Global Dialogue, Volume I3 Number I. Winter/Spring 20I I-Failed States

Falaki, A.J. (2007). Leadership. (5th Ed.). New York: Houghton Mifflin.

Hakam, I. A (1967.) .Sirah Omar bin Abd Aziz, Dar Malayin, Beiru.

IbnTaymiyyah. (I300 (AH)) As-Siyasah ash-Shariyyah[The Principles of religious government]. Cairo, Egypt: Dar El-Shaab.

Lukman, T. (I995) The Islamic polity and Leadership. Baron production SdnBhd. Mawdudi, A. (I982) Faith and Power: The Politics of Islam, Vintage Books.

Musaddad A I (2018) Islamic Political Administration: a Methods Towards a Good Governance in Africa. In AKINWUMI O Edition of conference Proceedings on Humanities and Burden of Governance in Africa, Ist Annual International conference, organized by the Faculty of Arts, Nasarawa State University keffi-Nigeria, November 2018, page 88-96.

Musaddad A I \& Muallimu (2019) Good Governance in Islam: The Nigerian Experience. In IKONOMIKA Jurnal Ekonomi dan Bisnis Islam, volume 4, No. 2 page 243-254, ISSN: 25273434

Musaddad A I \& Pali G A (2019) Prophet Muhammad SAW A Statesman and Administrator of Sustainable Developement . In Muhibbudeen M A Edition of conference Proceedings on Islam politics and Sustainable Development, $4^{\text {th }}$ Annual International conference, organized by the Department of Islamic studies Nasarawa State University keffi-Nigeria, June 2019, page I0-I8, ISSN: 25455648. Sulaiman, I, (I987) (The Islamic State and the Challenge of History: Ideals, Policies and Operation of the

Sokoto Caliphate. England: Mansell Publishing.

Tukur, M (2009). Islam And Leadership In Nigeria Jos MSS Leadership Training.

Yusuf, O. Umar bin Abdul'Aziz, retrieved v ia www.islamreligion.com website on I/04 

